DOI: $10.17951 / \operatorname{lrp} .2019 .38 .2 .55-65$

\author{
AndRZEj Chudnicki \\ Uniwersytet Marii Curie Skłodowskiej w Lublinie \\ ORCID: 0000-0002-3951-5752
}

\title{
DIAGNOZA FUNKCJONALNA W RESOCJALIZACJI
}

\begin{abstract}
Streszczenie: Celem artykułu jest zwrócenie uwagi na konieczność opracowania zestawów podstawowych ICF dla niedostosowania społecznego oraz dla zagrożenia niedostosowaniem społecznym. Wraz z reformą systemu oświaty wprowadzone zostały zmiany w dotychczasowym podejściu do specjalnych potrzeb edukacyjnych, jak również sposobu ich rozpoznawania. Nowe rozwiązania zostały oparte na modelu biopsychospołecznym, który zakłada uwzględnienie w diagnozie kontekstu funkcjonowania dziecka w środowisku nauczania i wychowania. W nowym podejściu diagnostycznym ocena funkcjonowania dziecka ma odbywać się na podstawie kategorii zawartych w Międzynarodowej Klasyfikacji Funkcjonowania, Niepełnosprawności i Zdrowia (ICF) oraz Międzynarodowej Klasyfikacji Funkcjonowania, Niepełnosprawności i Zdrowia - wersji dla dzieci i młodzieży (ICF-CY). Wymusza to wdrożenie nowych rozwiązań, również w zakresie diagnozy niedostosowania społecznego i zagrożenia niedostosowaniem społecznym.
\end{abstract}

Słowa kluczowe: niedostosowanie społeczne, zagrożenie niedostosowaniem społecznym, diagnoza funkcjonalna, resocjalizacja

\section{WPROWADZENIE}

Na przełomie XX i XXI wieku dominującym trendem w pedagogice specjalnej stała się inkluzja społeczna. Na zorganizowanej w 1994 r. w Salamance przez Organizację Narodów Zjednoczonych dla Wychowania, Nauki i Kultury, Światowej Konferencji Dotyczącej Specjalnych Potrzeb Edukacyjnych Dostęp i Jakość przyjęto Deklarację oraz wytyczne dla działań w zakresie specjalnych potrzeb edukacyjnych (UNESCO 1994). Celem proponowanych zmian było zapewnienie „edukacji dla wszystkich”, gwarantującej każdemu dziecku pełne uczestnictwo i równe szanse edukacyjne. Jednocześnie krytykowano tradycyjny - segregacyjny model edukacji 
z instytucjami specjalnymi i nauczycielem skupionym na nauczanym przedmiocie. Znacznie poszerzony został również katalog osób wymagających wsparcia. Za dzieci o specjalnych potrzebach edukacyjnych uczestnicy konferencji uznali nie tylko niepełnosprawne, lecz również utalentowane, „dzieci ulicy”, pracujące, wychowywane w społecznościach koczowniczych czy odległych, dzieci z mniejszości językowych, etnicznych czy kulturowych oraz dzieci z innych regionów lub grup nierównych szans czy z marginesu.

Realizacja nowych idei wymagała odejścia od dochodowego, negatywnego definiowania zdrowia rozumianego jako braku choroby, a także zaprzestania traktowania jej jako patologii organizmu, braku funkcjonalności lub niesprawność wybranych narządów, organów lub układów (Domaradzki 2013). Nowa społeczna perspektywa sytuowała problem $\mathrm{w}$ barierach $\mathrm{w}$ otoczeniu, uniemożliwiających człowiekowi pełne funkcjonowanie i zaspokajanie potrzeb, a tym samym pogarszających jakość jego życia. Nowe idee były zbieżne z przyjętą przez Światową Organizacją Zdrowia definicją zdrowia określającą zdrowie jako stan zupełnej pomyślności fizycznej, umysłowej i społecznej, a nie jedynie brak choroby lub ułomności (Konstytucja WHO, 1948).

Źródłem pozytywnego dobrostanu (zdrowia psychicznego) miała być poprawa jakości życia, umożliwiająca ludziom doświadczanie go jako sensownego, pozwalającego być twórczymi i aktywnymi obywatelami (World Health Organization 2013). Wiązało się to z zapewnieniem grupom i jednostkom marginalizowanym możliwości i zasobów umożliwiających im pełne uczestnictwo w życiu ekonomicznym, społecznym i kulturowym oraz zachowanie równego $z$ innymi obywatelami standardu życia, partycypacji w procesach decyzyjnych oraz dostępu do podstawowych praw (European Commission 2004). Na przełomie XX i XXI wieku inkluzja społeczna była już wiodącym trendem w polityce społecznej i międzynarodowych regulacjach prawnych. Idee te szybko przeniknęły do oświaty, gdzie jednym z priorytetowych celów stała się edukacja włączająca.

Pomimo zmian jakie zachodziły w Polsce i na świecie, jako dominujące, szczególnie w praktyce pedagogicznej, utrzymywało się tradycyjne podejście. Pedagogika specjalna - w swym klasycznym ujęciu - opierając się na paradygmacie psychomedycznym, preferowała arbitralnie planowane i korygujące „rozwiązania specjalne". Obejmowały one, realizowane przez specjalistów na podstawie diagnozy deficytów, rehabilitację osób obarczonych niepełnosprawnością oraz resocjalizację osób niedostosowanych (Sękowska 1998, s. 13). Przedmiotem zainteresowania pedagogiki resocjalizacyjnej, będącym jej subdyscypliną, była więc pomoc osobom niedostosowanym i zagrożonym niedostosowaniem społecznym $\mathrm{w}$ dostosowaniu się do oczekiwań społecznych. Oddziaływania resocjalizacyjne, oparte na modelu medycznym, z założenia poprzedza diagnoza klasyfikacyjna (segregacyjna). 
Badający, analizując głównie parametry behawioralne i osobowe, skupia się na zaburzonych strukturach i funkcjach jednostek niedostosowanych społecznie.

\section{NOWE REGULACJE DOTYCZĄCE KSZTAŁCENIA UCZNIÓW NIEDOSTOSOWANYCH I ZAGROŻONYCH NIEDOSTOSOWANIEM SPOŁECZNYM}

W polskich przepisach oświatowych zawarty jest szereg regulacji mających na celu włączenie uczniów z różnymi potrzebami edukacyjnymi do grupy rówieśniczej i zapewnienie im wszechstronnego wsparcia. Pojęcie specjalnych potrzeb edukacyjnych traktowane jest bardzo szeroko i odnosi się do uczniów, którzy z powodu większych niż ich rówieśnicy trudności w uczeniu się nie mogą podołać wymaganiom powszechnie obowiązującego programu edukacyjnego i nie są w stanie kontynuować nauki bez pomocy psychologiczno-pedagogicznej (Bogdanowicz 1995). Zgodnie z $\$ 3$ pkt 1 rozporządzenia w sprawie zasad udzielania i organizacji pomocy psychologiczno-pedagogicznej w publicznych przedszkolach, szkołach i placówkach (Rozporządzenia MEN z dnia 28 sierpnia 2017 r.), uczniowi o specjalnych potrzebach edukacyjnych udziela się pomocy psychologiczno-pedagogicznej. Rozporządzenie określa również sytuacje, w których w szczególności zachodzi konieczność jej udzielenia, wskazując na:

- niepełnosprawność,

- niedostosowanie społeczne,

- zagrożenie niedostosowaniem społecznym,

- zaburzenia zachowania lub emocji,

- szczególne uzdolnienia,

- specyficzne trudności w uczeniu się,

- deficyty kompetencji i zaburzeń sprawności językowych,

- choroby przewlekłe,

- sytuacje kryzysowe lub traumatyczne,

- niepowodzenia edukacyjne,

- zaniedbania środowiskowe związane z sytuacją bytową ucznia i jego rodziny, sposobem spędzania czasu wolnego i kontaktami środowiskowymi,

- trudności adaptacyjne związane z różnicami kulturowymi lub ze zmianą środowiska edukacyjnego w tym związanych z wcześniejszym kształceniem za granicą.

Pomoc psychologiczno-pedagogiczna polega na „rozpoznawaniu i zaspokajaniu indywidualnych potrzeb rozwojowych i edukacyjnych ucznia oraz rozpoznawaniu indywidualnych możliwości psychofizycznych ucznia i czynników 
środowiskowych wpływających na jego funkcjonowanie w szkole i placówce w celu wspierania potencjału rozwojowego ucznia i stwarzania warunków do jego aktywnego i pełnego uczestnictwa w życiu szkoły i placówki oraz w środowisku społecznym" (tamże).

W Polsce dzieciom i młodzieży za specjalnymi potrzebami edukacyjnymi (SPE) oferuje się wiele ścieżek edukacyjnych umożliwiających wybór właściwej formy kształcenia poprzez korzystanie z kształcenia ogólnodostępnego, integracyjnego oraz specjalnego. W systemie segregacyjnym umieszcza się jedynie dzieci, którym wydaje się orzeczenia o potrzebie kształcenia specjalnego ze względu na niepełnosprawność, niedostosowanie społecznie lub zagrożenie niedostosowaniem społecznym (Rozporząazenia MEN z dnia 7 września 2017 r.). Obecnie dla dzieci i młodzieży niedostosowanej społecznie i zagrożonej niedostosowaniem społecznym przeznaczone są dwa typy placówek specjalnych:

- młodzieżowe ośrodki wychowawcze (MOW) dla młodzieży wymagającej resocjalizacji z powodu trudności w realizacji standardów wymagań programowych wynikających ze specyfiki ich funkcjonowania poznawczo-percepcyjnego, zdrowotnego oraz ograniczeń środowiskowych;

- młodzieżowe ośrodki socjoterapii (MOS) dla dzieci i młodzieży wymagających socjoterapii z powodu zaburzeń rozwojowych, trudności w uczeniu się i zaburzeń w funkcjonowaniu społecznym (Rozporządzenie MEN $\mathrm{z}$ dnia 2 listopada $2015 \mathrm{r}$.)

Pomimo że oba typy placówek funkcjonują równolegle w systemie oświaty, to sposób kierowania do nich jest odmienny. W młodzieżowych ośrodkach wychowawczych (MOW) umieszczani są nieletni, wobec których sąd orzekł zastosowanie takiego właśnie środka wychowawczego. Podstawą decyzji jest nie tylko popełnienie przez nich czynów karalnych, lecz również przejawy demoralizacji obejmujące m.in. naruszanie zasad współżycia społecznego, systematyczne uchylanie się od obowiązku szkolnego lub kształcenia zawodowego, używanie alkoholu lub innych środków w celu wprowadzenia się w stan odurzenia, uprawianie nierządu czy włóczęgostwo (Ustawa z dnia 26 października 1982 r.). Wydanie orzeczenia poprzedza diagnoza sporządzona najczęściej przez opiniodawcze zespoły specjalistów sądowych, potwierdzająca potrzebę zastosowania takiego środka wychowawczego. Ukierunkowana jest na określenie etiologii, patogenezy i objawów demoralizacji nieletniego. Do sporządzenia opinii dla sądu, zespoły diagnostyczne korzystają głównie $\mathrm{z}$ analizy akt, badania psychologiczno-pedagogicznego w tym $\mathrm{z}$ trzech głównych technik: rozmów/wywiadu klinicznego, obserwacji i testów osobowości (Włodarczyk-Madejska 2016 s. 168). Przesłana do sądu opinia zawiera konkluzję w postaci zalecenia odnośnie zastosowania wobec nieletniego środka wychowawczego w postaci umieszczenia w młodzieżowym ośrodku wychowawczym. 
Skierowanie do młodzieżowego ośrodka socjoterapii (MOS) poprzedza wydanie przez uprawnioną poradnię psychologiczno-pedagogiczną orzeczenia o potrzebie kształcenia specjalnego ze względu na zagrożenie niedostosowaniem społecznym. Wydawany przed wprowadzeniem nowych regulacji prawnych dokument zawierał diagnozę, w tym informacje o możliwościach rozwojowych i potencjale dziecka, zalecenia dotyczące warunków realizacji pomocy psychologiczno-pedagogicznej, a także uzasadnienie proponowanej formy kształcenia specjalnego (Rozporządzenie MEN z dnia 18 września 2008 r.).

Pomimo opierania się na paradygmacie psychomedycznym, diagnoza niedostosowania społecznego i zagrożenia niedostosowaniem społecznym nie jest sensu stricto diagnozą nozologiczną, która z założenia powinna prowadzić do rozpoznania zjawiska i jego klasyfikacji na podstawie charakterystycznej etiologii, patogenezy oraz objawów. Według E. Wysockiej (2008 s. 85) w klasyfikacji osób niedostosowanych społecznie pojawiają się bowiem trudności wynikające z braku norm dotyczących objawów oraz z polietiologicznego charakteru zaburzeń uwikłanego w standardy kulturowe. Skutkuje to tym, że pojęcia niedostosowania społecznego i zagrożenia niedostosowaniem społecznym nie zostały jednoznacznie zdefiniowane i nie występują jako odrębna jednostka nozologiczna w dostępnych międzynarodowych klasyfikacjach (np. ICD-10 lub DSM-V). Powoduje to, że pojęcia niedostosowania społecznego czy też zagrożenia niedostosowaniem społecznym obejmują osoby spełniające kryteria zaburzeń psychicznych i zaburzeń zachowania (m.in. zaburzeń nerwicowych, depresyjnych, dyssocjalnych, hiperkinetycznych, zaburzeń zachowania i emocji czy spowodowanych nadużywaniem substancji psychoaktywnych) jak i osoby niespełniające w pełni kryteriów żadnego z zaburzeń lub też takie, których funkcjonowanie wynika z czynników somatycznych, kulturowych czy środowiskowych. W praktyce wydanie przez poradnię psychologiczno-pedagogiczną orzeczenia o potrzebie kształcenia specjalnego dla ucznia niedostosowanego społecznie czy zagrożonego niedostosowanie społecznym jest przede wszystkim wynikiem oceny zasadności zastosowania wobec niego specjalnej organizacji nauki, metod pracy i wychowania, pomocy psychologiczno-pedagogicznej oraz - odpowiednio - resocjalizacji lub socjoterapii. Zdaniem E. Wysockiej (2008 s. 110) „w diagnozie niedostosowania społecznego chodzi zatem o odpowiedzenie na pytanie, czy nasilenie objawów występujących u jednostki jest na tyle wysokie, że można mówić o zespole klinicznym, czyli w języku pedagogiki resocjalizacyjnej - niedostosowaniu społecznym, czy zaburzeniach mogących doń prowadzić”.

Brak jednoznacznych kryteriów umożliwiających trafną diagnozę nozologiczną, a jednocześnie posługiwanie się aparatem pojęciowym modelu medycznego, sprzyja „medykalizacji” problemów uczniów sprawiających różne kłopoty wychowawcze. W sposób naturalny umiejscawia to problemy po stronie ucznia, wysuwając na 
pierwszy plan jego niedostosowanie oraz wynikające $\mathrm{z}$ tego trudności dla rodziców, nauczycieli czy specjalistów i uzasadnia traktowanie ich jako wymagających specjalnych metod kształcenia i wychowania. Uczeń ze specjalnymi potrzebami staje się problemem, którym powinni zająć się specjaliści pracujący w specjalnie powołanych w tym celu instytucjach. Sprzyja to wykluczaniu i instytucjonalizacji osób sprawiających w szkole trudności wychowawcze i edukacyjne, nadając im stygmat niedostosowanych lub zagrożonych niedostosowaniem społecznym. Brak jednoznacznych kryteriów ułatwia stosowanie rozwiązań specjalnych i może prowadzić do instytucjonalizacji dzieci sprawiających trudności wychowawcze, które nie wymagają stosowania aż tak radykalnych rozwiązań. Zdaniem B. Stańdo-Kaweckiej (2007), obowiązujące przepisy prawne zwykle zapewniają takim osobom znacznie słabsze gwarancje niż dorosłym.

Niewłaściwa selekcja powoduje również trudności w planowaniu i realizacji skutecznych działań resocjalizacyjnych. Aby mogły być one skuteczne, niezbędny jest precyzyjny pomiar i selekcja oraz objęcie osób resocjalizowanych działaniami o potwierdzonej naukowo skuteczności (Andrews, Bonta 2010). Zgodnie z założeniami modelu RNR, skuteczna interwencja korekcyjna musi spełniać trzy zasady:

1) Zasadę ryzyka, zgodnie z którą poziom intensywności oddziaływań powinien być uzależniony od nasilenia problemów;

2) Zasadę potrzeb, która wskazuje, że interwencja powinna dotyczyć przede wszystkim czynników silnie skorelowanych z przestępczością;

3) Zasadę reaktywności, wskazującą że działania powinny być dostosowane do możliwości osób resocjalizowanych (Andrews, Bonta 2007; Looman, Abracen 2013; Stańdo-Kawecka 2013).

Zgodnie z nowymi przepisami dotyczącymi orzeczeń i opinii wydawanych przez zespoły orzekające działające w publicznych poradniach psychologiczno-pedagogicznych (Rozporządzenie MEN z dnia 7 września 2017 r.), prawidłowa opinia lub orzeczenie przygotowane przez poradnie psychologiczno-pedagogiczne powinnyy zawierać informację o funkcjonowaniu ucznia z uwzględnieniem jego potencjału rozwojowego, mocnych stron i uzdolnień oraz informacje o występujących w środowisku ucznia zasobach, barierach i ograniczeniach utrudniających jego funkcjonowanie. W orzeczeniu powinny również znaleźć się zalecenia dotyczące warunków i form wsparcia umożliwiających realizację celów rozwojowych i terapeutycznych oraz indywidualnych potrzeb rozwojowych i edukacyjnych ucznia. Orzeczenie powinno zawierać także zalecenia dotyczące realizacji zajęć edukacyjnych, socjoterapeutycznych i resocjalizacyjnych.

Nowa diagnoza ma stanowić wielowymiarowy opis funkcjonowania ucznia w modelu $\mathrm{ABC}$, obejmującym współzależne przyczyny trudnego zachowania (antecedents - A), jego charakterystykę (behawior - B) oraz skutki (concequences - C). 
Ocena zachowania powinna stanowić podstawę do zaprojektowania oddziaływań mających na celu redukcję zachowań problemowych i stymulację zachowań pożądanych (Domagała-Zyśk i in. 2017). „Głównym celem tak rozumianej diagnozy funkcjonalnej jest rozpoznanie czynników środowiskowych, warunkujących wystąpienie zachowania problemowego, opis jego przebiegu oraz konsekwencji, udzielenie uczniowi wsparcia i zastąpienie zachowania niepożądanego bardziej akceptowanym społecznie" (Domagała-Zyśk i in. 2017 s. 52).

Nowe rozwiązania wymagają od zespołów diagnostycznych odniesienia się w diagnozie do Międzynarodowej Klasyfikacji Funkcjonowania, Niepełnosprawności i Zdrowia (International Classification of Functioning, Disability and Health, ICF) (Wargocka 2016). Jest to jedna $\mathrm{z}$ międzynarodowych klasyfikacji opracowanych przez Światową Organizację Zdrowia (WHO), stosowana do opisu różnych aspektów zdrowia. W odróżnieniu od Międzynarodowej Statystycznej Klasyfikacji Chorób i Problemów Zdrowotnych (International Statistical Classification of Diseases and Related Health Problems, ICD-10), która jest klasyfikacją nozologiczną, ICF jest klasyfikacją cech charakterystycznych stanu zdrowia człowieka w kontekście jego indywidualnej sytuacji życiowej oraz wpływów otaczającego środowiska. Pozwala na kodowanie szerokiego zakresu informacji o stanie zdrowia i posługiwanie się wystandaryzowanym, wspólnym językiem (ICF 2001 s. 3). Międzynarodowa Klasyfikacja Funkcjonowania, Niepełnosprawności i Zdrowia opiera się na połączeniu dwóch skrajnych modeli. Integrując model medyczny i społeczny, rozpatruje się kwestie zdrowia z perspektywy biopsychosocjalnej (Byra, Boczkowska, Duda 2016). Dzięki temu pozwala ona uzyskać obraz rozmaitych wymiarów zdrowia na poziomie biologicznym, jednostkowym i społecznym, jednocześnie nie obejmuje jednak tych sytuacji, które nie są związane ze stanem zdrowia, ale są wywołane przez czynniki socjoekonomiczne (WHO 2007).

Kategorie w ICF zorganizowane są w dwóch częściach. Pierwsza obejmuje funkcje i struktury ciała ludzkiego oraz aktywność, działanie i uczestniczenie. Druga część to czynniki kontekstowe, w skład których wchodzą czynniki środowiskowe oraz indywidualne. Funkcjonowanie danej osoby w perspektywie ICF postrzegane jest jako dynamiczna interakcja pomiędzy stanem chorobowym (choroby, zaburzenia, uszkodzenia, urazy itp.) a tzw. czynnikami kontekstowymi (WHO 2007). W 2007 roku opracowana została również wersja Międzynarodowej Klasyfikacji Funkcjonowania, Niepełnosprawności i Zdrowia dla dzieci i młodzieży (International Classification of Functioning, Disability and Health: Children \& Youth Version - ICF-CY). Została zaprojektowana w celu uchwycenia szczególnej sytuacji rozwijającego się człowieka. Uwzględniono w niej konieczność postrzegania dziecka w kontekście jego rodziny i innych środowisk oraz zmian charakteru i form uczestnictwa w okresie dzieciństwa i dojrzewania. Klasyfikacja ICF-CY bierze również 
pod uwagę różnice rozwojowe pomiędzy dziećmi przy nabywaniu umiejętności czy rozwoju określonych funkcji (ICF-CY 2007). Światowa Organizacja Zdrowia zaleca stosowanie ICF oraz ICF-CY łączne z klasyfikacjami stosującymi podejście etiologiczne (ICD-10). Daje to bowiem możliwość całościowego rozumienia osoby i pozwala na skuteczniejsze i trafniejsze budowanie systemu wsparcia oraz tworzenie właściwych warunków rozwoju (Jurek, Pawlicka 2015).

\section{PODSUMOWANIE}

Zdaniem Ewy Wysockiej (2015) warunkiem efektywności procesu resocjalizacji jest współzależność pomiędzy procesem diagnostycznym a realizowanymi oddziaływaniami. Aby diagnoza mogła być podstawą projektowania działań resocjalizacyjnych, oba procesy powinny być realizowane $\mathrm{w}$ jednym paradygmacie teoretyczno-metodologicznym. W praktyce oznacza to zarówno dostosowanie diagnozy niedostosowania społecznego i zagrożenia niedostosowaniem społecznym do modelu społecznego, jak również projektowania i realizacji działań w tym paradygmacie. Nowa społeczna perspektywa wymusza zatem odmienne spojrzenie na uczniów niedostosowanych i zagrożonych niedostosowaniem społecznym. Identyfikując ich problemy jako bariery uniemożliwiające im prawidłowe funkcjonowanie, wymaga uznania za priorytet $\mathrm{w}$ resocjalizacji wspomaganie procesu rozwoju osobowego i społecznego osób niedostosowanych społecznie.

Do realizacji nowych założeń niezbędne wydaje się w najbliższym czasie opracowanie oficjalnych podstawowych zestawów ICF-CY dla niedostosowania i zagrożenia niedostosowaniem społecznym, będących krótkimi listami kategorii, które można uznać za najbardziej odpowiednie dla tych zaburzeń. Pozwoliłoby to stworzyć narzędzia diagnostyczne (np. ankiety, wywiady, skale obserwacji itp.) służące do ich rozpoznania oraz umożliwiłoby uchwycenie różnorodnych profili funkcjonalnych osób niedostosowanych społecznie i zagrożonych niedostosowaniem społecznym. Dzięki temu możliwe byłoby lepsze zaprojektowanie oddziaływań z wykorzystaniem obowiązujących indywidulanych programów edukacyjno-terapeutycznych (IPET).

Odniesienie do kategorii ICF-CY umożliwiłoby ujednolicenie języka, jakim posługują się instytucje zaangażowane w pomoc osobom niedostosowanym i zagrożonym niedostosowaniem społecznym. Umożliwiłoby to lepszą współpracę oraz możliwość wspólnego planowania oddziaływań. Dzięki odniesieniu do ICF, możliwe stałoby się dokonywanie porównań międzynarodowych. Jest to szczególnie istotne ze względu na trudności w ocenie skuteczności przy adaptacji zagranicznych rozwiązań. 


\section{LITERATURA}

Andrews, D.A., Bonta, J. 2010, The psychology of criminal conduct (5th ed.). Newark, NJ, LexisNexis/Matthew Bender.

Andrews, D.A., Bonta, J. (2007). Risk-Need-Responsivity Model for Offender Assessment and Rehabilitation (2007-06). Ottawa, Public Safety Canada.

Bogdanowicz M., 1995, Uczeń o specjalnych potrzebach edukacyjnych. „Psychologia Wychowawcza”, 3, s. 216-223.

Byra S., Boczkowska M., Duda M., 2016, Współczesne konteksty znaczeniowe terminu „niepełnosprawnośc” - implikacje Międzynarodowej Klasyfikacji funkcjonowania, Niepełnosprawności i Zdrowia (ICF). „Człowiek - Niepełnosprawność - Społeczeństwo", 4, s. 15-32.

Domaradzki J., 2013, O definicjach zdrowia i choroby. „Folia Medica Lodziensia”, 40/1, s. 5-29.

Domagała-Zyśk, E., Knopik, T., Oszwa, U. (2017). Diagnoza funkcjonalna rozwoju społeczno-emocjonalnego uczniów w wieku 9-13 lat. Lublin.

European Commission. Directorate-General for Employment, \& Social Affairs. Unit E. (2004). Joint report on social inclusion. Office for Official Publications of the European Communities.

Jurek P., Pawlicka P., 2015, Kwestionariusz diagnozy funkcjonalnej. Gdańsk.

Wargocka T., 2016, Odpowiedź na interpelację nr 8126 w sprawie reformy edukacji http:// www.sejm.gov.pl/Sejm8.nsf/InterpelacjaTresc.xsp?key=065AE706 (dostęp 24.08.2018).

Looman, J., Abracen, J., 2013, The risk need responsivity model of offender rehabilitation: is there really a need for a paradigm shift? „International Journal of Behavioral Consultation and Therapy", 8, 3-4, s. 30-36. http://dx.doi.org/10.1037/h0100980 (dostęp: 14.11.2017).

Rozporządzenie MEN z dnia 18 września 2008 r. w sprawie orzeczeń i opinii wydawanych przez zespoły orzekające działające w publicznych poradniach psychologicznopedagogicznych (Dz.U. 2008 nr 173 poz. 1072)

Rozporządzenie MEN z dnia 2 listopada 2015 r. w sprawie rodzajów i szczegółowych zasad działania placówek publicznych, warunków pobytu dzieci i młodzieży w tych placówkach oraz wysokości i zasad odpłatności wnoszonej przez rodziców za pobyt ich dzieci w tych placówkach (Dz.U. 2015 poz. 1872)

Rozporządzenia MEN z dnia 28 sierpnia 2017 r. zmieniające rozporządzenie w sprawie zasad udzielania i organizacji pomocy psychologiczno-pedagogicznej w publicznych przedszkolach, szkołach i placówkach (Dz.U. 2017 poz. 1643)

Rozporządzenia MEN z dnia 7 września 2017 r. w sprawie orzeczeń i opinii wydawanych przez zespoły orzekające działające w publicznych poradniach psychologicznopedagogicznych Dz.U. 2017 poz. 1743) 
Sękowska, Z.,1998, Wprowadzenie do pedagogiki specjalnej. Warszawa.

Stańdo-Kawecka B., 2007, Prawo karne nieletnich. Od opieki do odpowiedzialności. Warszawa.

Stańdo-Kawecka B. (2013). Wykonywanie kary pozbawienia wolności z perspektywy współczesnej penologii. W: Szczepaniak P. (red), Polski system penitencjarny. Ujęcie integralno-kulturowe. Warszawa.

Światowa Organizacja Zdrowia, 2009. Międzynarodowa Klasyfikacja Funkcjonowania Niepełnosprawności i Zdrowia (ICF). Warszawa, Centrum Systemów Informacyjnych Ochrony Zdrowia.

UNESCO, 1994, Deklaracja oraz wytyczne dla działań w zakresie specjalnych potrzeb edukacyjnych. United Nations Educational, Scientific and Cultural Organization, Salamanca.

Ustawa z dnia 26 października 1982 r. o postępowaniu w sprawach nieletnich. „Dziennik Ustaw” 1982 nr 35 poz. 228.

Konstytucja WHO, 1948, „Dziennik Ustaw” 1948 nr 61, poz. 477.

Włodarczyk-Madejska J., 2016, Stosowanie środka wychowawczego w postaci umieszczenia $w$ młodzieżowych ośrodkach wychowawczych oraz środka poprawczego przez sady rodzinne i nieletnich $w$ świetle danych statystycznych i badań aktowych. Instytut Wymiar Sprawiedliwości Warszawa, https://www.iws.org.pl/ pliki/files/W\%C5\%82odarczyk-Madejska\%20J_Stosowanie\%20\%C5\%9Brodka\%20 wychowawczego.pdf (dostęp: 22.07.2018).

WHO, 2001, International Classification of Functioning, Disability and Health (ICF). Geneva.

WHO, 2004, Promoting mental health: concepts, emerging evidence, practice (Summary Report). Geneva, http://www.who.int/mental_health/evidence/en/promoting_mhh.pdf

WHO, 2007, International classification of functioning, disability and health: children and youth version: ICF-CY. World Health Organization. https://apps.who.int/iris/ handle/10665/43737 (dostęp 22.08.2018).

WHO, 2013, Europejski Raport Zdrowia. Droga do osiagnięcia dobrostanu. Streszczenie. Kopenhaga, World Health Organization Regional Office for Europe.

Wysocka E., 2008, Diagnoza w resocjalizacji: obszary problemowe i modele rozwiązań w ujęciu psychopedagogicznym. Warszawa.

Wysocka E., 2015, Diagnoza pozytywna w resocjalizacji. Model teoretyczny i metodologiczny. Katowice, Wydawnictwo UŚ. 


\title{
FUNCTIONAL DIAGNOSIS IN RESOCIALIZATION
}

\begin{abstract}
The aim of the article is drawing attention to the necessity to develop ICF core sets for social maladjustment and the danger of social maladjustment. Along with the reform of the educational system we have seen the introduction of the changes in the existing approach to special educational needs, as well as to the way of their identification. The new solutions have been based on biopsychosocial model, which in the diagnosis takes into account the context of functioning of a child in teaching and nurturing environment. In the new diagnostic approach, the assessment of functioning of a child should take place based on categories included in International Classification of Functioning, Disability and Health (ICF) and in International Classification of Functioning, Disability and Health - the version for children and youth (ICF-CY). It forces the implementation of new solutions also within the diagnosis of social maladjustment and the danger of social maladjustment.
\end{abstract}

Keywords: social maladjustment, danger of social maladjustment, functional diagnosis, resocialization 